シンポジウム

「口腔癌に対する癌ワクチン療法の現状と展望」

\title{
腫瘍特異的抗原由来ペプチドを用いた癌ワクチン療法 〜臨床試験について〜
}

\author{
吉 武義泰福間大喜 篠 原 正 徳
}

\begin{abstract}
要旨：癌に対する第 4 の治療法として期待され続けてきた免疫療法であるが, これまでは溶連菌の乾燥菌体による OK-432（ピシバニール ${ }^{\circledR}$ ) やカワラタケから抽出した蛋白多糖複合体である PSK（クレスチン ${ }^{\circledR}$ )，シイタケより抽出 された多糖類であるレンチナンなどが癌治療に用いられてきた。しかし，それらを投与しても非特異的に患者の免疫 力を高めるだけであり, 癌細胞への選択性はまったくない。それに対し癌ワクチン療法, 特に今回われわれが新たに 投与を開始したペプチドワクチン療法は，非常に選択的に癌細胞だけを標的とすることのできる特定のリンパ球だけ を増やすことを目指した治療法である。本文にて，われわれが実施している口腔癌に対する癌ぺプチドワクチン療法 の現状について報告する。
\end{abstract}

キーワード : 癌ワクチン療法, ペプチドワクチン療法, 口腔癌

\section{はじめに}

2011 年 1 月 27 日に行われた第 29 回日本口腔腫瘍学会 のシンポジウム 1 にて発表した内容をもとに, 癌免疫療法 のうちのペプチドワクチン療法に関して述べることとす る。

癌治療において, 現在エビデンスに基づく治療法として 確立しているのは外科療法, 化学療法, 放射線療法の 3 療 法である。癌が局所に限局している場合には外科療法と放 射線療法が特に有効である。一方, 癌が全身に広がってい る場合，それは転移・再発して全身に癌が発症している場 合と, 手術やその他の治療をうけた後に目には見えないレ ベルで全身に広がっている場合が考えられるが，そのどち らの場合に対しても化学療法と第 4 の治療法と言われてい る免疫療法が有効となると考えられる。これまで免疫療法 については限られた状況に扔いて効果を認めることがあっ たものの，その科学的なエビデンスは十分に解明されてい なかった。癌免疫療法とは患者自身の免疫を活性化し, 免 疫系細胞や体内で作られた抗体によって癌細胞を攻撃させ ることによって抗癌作用を示す治療法である。そもそも 癌細胞自体が自己の細胞であり，それを攻撃するのも自己 の免疫細胞あるいはそれが産生した抗体ということになる

熊本大学大学院生命科学研究部総合医薬科部門顎口腔病態学 分野 (主任 : 篠原正徳教授)

〔受付：2011 年 10 月 3 日, 受理 : 2011 年 10 月 28 日〕
ので, 標的抗原分子の選定が重要となってくる。まずは癌 特異的抗原分子の同定から話を進める。

\section{1. 口腔癌特異的抗原分子の同定}

癌ワクチン療法は細胞レベルで腫瘍を攻撃できることか ら, 特に局所再発や遠隔転移に対する抑制効果が期待され ている。癌ペプチドワクチン療法において重要なのは, T 細胞をより強く活性化できる抗原ペプチドを同定すること である。がん特異的に発現して HLA class I と強く結合 し，免疫療法の標的となった場合でも免疫系からの逃避が 起こりにくい抗原ペプチドが条件となる。

近年, 癌細胞に特異的に発現している遺伝子を網羅的に 探索できるようになった。採取した癌組織から作製した 組織標本を顕微鏡で見ながら LMM（Laser Microbeam Microdissection）を用いて癌細胞部分と正常細胞部分とに 分離し採取を行い，それぞれより mRNAを抽出し，マイ クロアレイを用いて遺伝子発現の解析を行う。それによっ て，ヒト遺伝子あるいは EST 約 20,000 種類の遺伝子から 癌細胞における詳細な遺伝子発現情報（正常細胞には発現 していないが, 癌細胞には特異的に高発現している遺伝子 の情報など）を得ることができる。その中から癌特異的抗 原分子を同定していくことになるのだが，免疫療法への応 用を考える場合には，多くの患者に使えるという共通性 (発現頻度), 癌特異性, 免疫原性, 腫瘍拒絶能, 抗原消失 性，自己免疫などの副作用，などによって各抗原分子の 

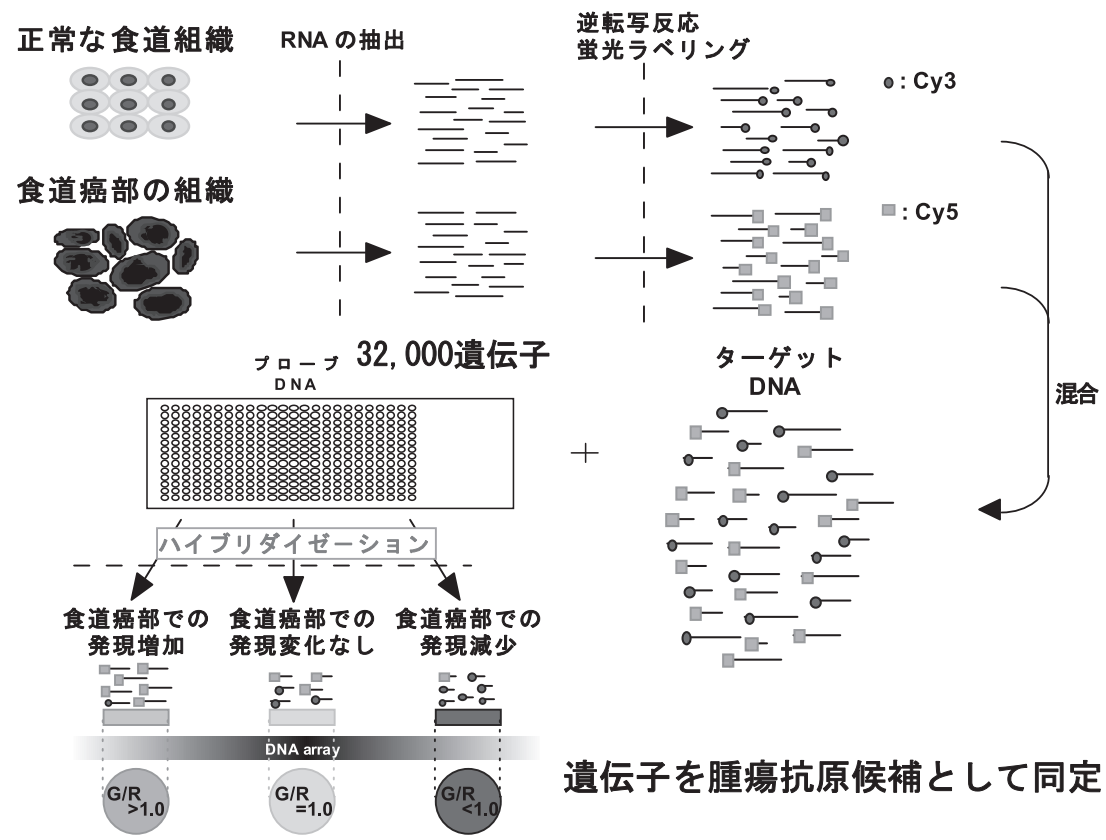

図 1 マイクロアレイ解析法の概要

特徵をとらえる必要がある。理想的な癌拒絶抗原が備えて いるべき性質として以下の 3 つが考えられている。I）癌 患者の体内において免疫応答を誘導する抗原; 癌細胞の拒 絶までは至らないとしても, 癌患者の血液中に抗原特異的 な抗体や T細胞の存在が検出できるもの。II）発現の組織 特異性が優れた抗原; 癌細胞での発現は強いが, 正常組織 には発現しておらず，腫瘍抗原に対する免疫応答が重篤な 自己免疫疾患を誘導しないもの。たとえば，胎児期組織抒 よび癌組織のみに発現する癌胎児性抗原や, 癌細胞と免疫 系から隔離された組織のみに発現する癌精巣抗原（CT 抗 原）など。III）免疫系からの逃避が起こりにくい抗原； 癌細胞の悪性形質転換, 組織浸潤や転移に重要な役割を 担っている分子で, 癌細胞がその発現を欠落すると, 癌の 悪性形質を失うもの, である。

現在までに同定されているヒト癌抗原を分類すると，(1) cancer-testis 抗原, (2)組織特異抗原 (tissue specific antigen), (3)変異ペプチド抗原, (4)癌遺伝子, 癌抑制遺伝子 （tumor suppress）産物, (5)癌胎児性抗原（carcinoembryonic antigen : CEA), (6)癌細胞で発現が増強している抗 原, などがあげられるが, T 細胞によって認識されるヒト 腫瘍抗原の同定法として以下の 4 つがあげられる。i）癌 化と関連した腫瘍抗原の候補に対する $\mathrm{T}$ 細胞応答の解析 ; 細胞の癌化に関連した癌遺伝子や癌抑制遺伝子産物の突然 変異部分, 融合蛋白質の境界部分, あるいはウイルス抗原 に由来するペプチドを特異的に認識する T 細胞を証明す る方法。(変異 Ras, 変異 p53, BCR/ABL, TEL/AML1 ほか） ii）癌細胞に特異的に反応する $\mathrm{T}$ 細胞株（クローン）
を利用して癌細胞由来の cDNA ライブラリーをスクリー ニングする方法。(MAGE-1/3，チロシナーゼ，gp100, Melan-A/MART-1, SART-1 ほか多数）iii）癌患者血清中 の抗腫瘍抗原 $\operatorname{IgG}$ を利用して癌細胞由来の $\mathrm{cDNA}$ ライブ ラリーをスクリーニング (SEREX 法) する方法。（NYESO-1 ほか多数）iv）cDNA マイクロアレイ解析を利用 して, 遺伝子発現の組織特異性から抗腫瘍免疫の誘導に 適した腫瘍抗原分子を同定し，その抗原性を解析する方 法。(proliferation potential-related protein $(\mathrm{PP}-\mathrm{RP})^{1)}$, Glypican-3 $(\mathrm{GPC} 3)^{2)}$, cell division cycle associated 1 $(\mathrm{CDCA} 1)^{3)}$ ほか)

cDNA マイクロアレイ解析の概略を図 1 に示した。腫 瘍抗原候補の同定に cDNA マイクロアレイ解析を用いる ことの最大の利点は, 一度に数千〜数万種類の遺伝子の発 現をスクリーニングできる点にある。そこでまず理想的な 癌拒絶抗原が備えているべき性質のうちの II）の条件を满 たす遺伝子を選出することができる。場合によっては III) の条件を満たす遺伝子を選出することもできる。さらに cDNA マイクロアレイ解析は患者毎に遺伝子発現を解析 することができるため, 癌組織において各遺伝子を高発現 する症例の頻度も知ることができる。

すでにわれわれは cDNA マイクロアレイ解析を用いて， 肝細胞癌で GPC3, 食道癌で PP-RP, 膵癌で Cadherin 3/ P-cadherin $(\mathrm{CDH} 3)^{4)}$ 遺伝子が特異的に高発現している ことを報告している。GPC3 は癌胎児性抗原で胎盤と肝細 胞癌細胞に高発現する遺伝子であり, PP-RP は cancerrelated autoantigen で胎盤と癌細胞にしか発現しない遺伝 


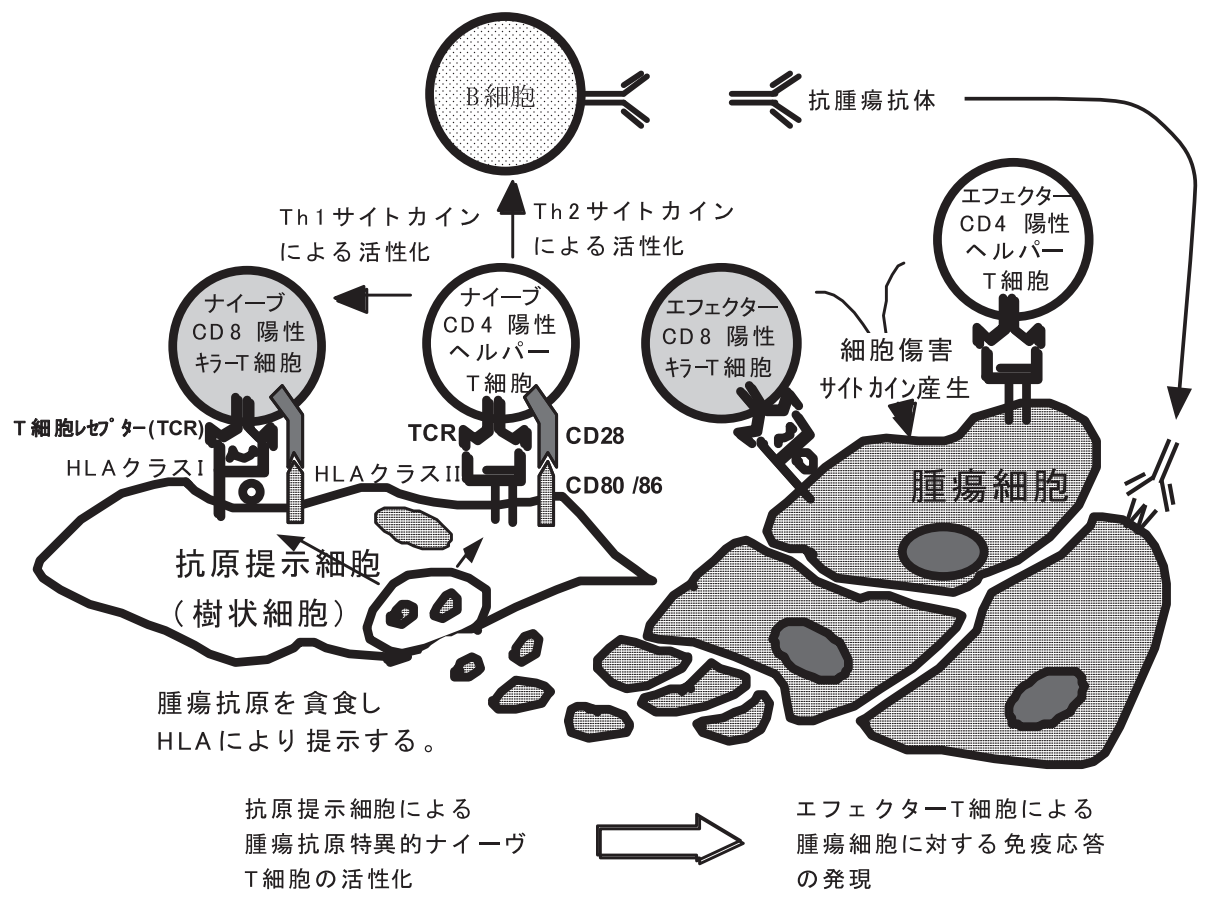

図 2

子で, $\mathrm{CDH} 3$ も同様の発現様式であった。これらの抗原は 発現様式の点において理想的な癌抗原であるといえた。そ こで, これらの抗原を発現している癌細胞株を傷害するこ とのできる細胞傷害性 T 細胞 (Cytotoxic T Lymphocyte : CTL）を誘導可能なぺプチドを同定することを試みた。 その結果, CTL を誘導することができる数種類のペプチ ドが同定された。肝細胞癌ではすでに, GPC3 由来のペプ チドを用いたペプチドワクチン療法の第 I ・ II 相臨床試験 が開始されている。

\section{2. 癌ペプチドワクチン療法のメカニズム}

このようにして同定された癌細胞特異的分子に由来する タンパク質のアミノ酸配列から HLA class I 拘束性のエピ トープペプチドを探索することにより，細胞傷害性 T 細 胞を誘導できる新規癌抗原ペプチドが同定されることと なった。そもそも, 同定された癌抗原は腫瘍の増殖や分化 にとって重要な機能を有すると考えられる分子 (Oncogene）であり，かつ高い抗原性を有して免疫細胞より認 識される抗原 (Antigen) ということで, Oncoantigen と 定義され，これらを治療標的とすることにより，これまで に同定されてきた抗原を用いたワクチンよりも癌細胞に対 して特異的で, かつ高い免疫誘導効果, 癌細胞排除効果が 期待できることとなった。

HLA class I 拘束性ペプチドを患者に投与すると, ペプ チドが樹状細胞（Dendritic cell：DC）によって抗原提示
され，それを認識した $\mathrm{T}$ 細胞がペプチド特異的細胞傷害 性 T 細胞 (peptide specific CTL) へと誘導される。一方, 標的となる癌細胞では標的分子由来の抗原タンパク質がプ ロセッシングを受けてペプチドとなり，HLA class I 分子 と結合し，HLA-ペプチド複合体として細胞表面に提示さ れている。ペプチド投与によって活性化された細胞傷害活 性を有した CTLが, ペプチドを提示している癌細胞を認 識できた時に初めて癌細胞は攻撃・傷害されることとな り, その結果, 癌細胞は消滅することとなる (図 2)。

ペプチドワクチンはこれまでの細胞毒性を持つ薬剤とは 異なり, ペプチドそのものは直接の薬理作用をもたず, 免 疫機構を介して間接的に作用を発揮するという点で安全性 を含めた薬剤の概念が既存の抗癌剂とは大きく異なってい る。そのために既存の抗癌剤の開発手法や評価方法が必ず しも通用せず，探索的臨床試験では患者一人ひとりの変化 を注意深く観察して幅広く情報を収集し, 科学的に評価し ていくことが重要となってくる。

\section{3. 口腔癌に対する癌ペプチドワクチン療法の現状}

口腔癌は, 口唇 ·上下顎歯肉 ·舌 $\cdot$ 口底 ·頓粘膜 $\cdot$ 口蓋 の領域に発生する悪性腫瘍であり, 多くは上皮由来であ る。Stage III 〜 IV の症例が約 $2 / 3$ を占め, 切除手術が行 われた症例でも局所再発することがあり, 約 $30 \%$ の症例 に遠隔転移も認める。扁平上皮癌が主体を占めており, 危 険因子としては喫煙, 飲酒があげられ, 発症年齢も 65 
75 歳にピークを認める高齢者に多い疾患である。従って, 癌だけでなく心・肺疾患や肝疾患, 代謝疾患を合併して いることも多い。また, 同時性に口腔領域で発症する多発 癌や, 食道癌や胃癌などとの重複癌の症例も $10 \%$ 程度で 認められる。治療方法としては手術や放射線治療が主体で あり, 本邦でこの疾患を取り扱っている科は, 歯科口腔外 科, 耳鼻咽喉科, 頭頸部外科, 放射線科（放射線治療科） などである。現状において口腔癌における化学療法の効果 は, 化学療法単独で治癒する可能性は $20 \%$ 程度である。 口腔は嚥下・発音といった機能, そして審美の面が患者の QOL に大きく影響するため, 化学療法を用いてこれらの 問題を解決するような研究が行われており，それが初回治 療として化学療法や化学療法併用放射線療法といった形で 行われている。同様に, ペプチドワクチン療法も非侵襲的 に口腔癌を治療することができるが，腫瘤を形成した癌に 対して, ペプチドワクチン単独で十分な効果を得ることは 難しい。今後, 術前治療として化学療法や放射線療法との 併用にて，その一翼を担えるようになることを期待してい る。一方，ペプチドワクチンによって活性化された免疫細 胞は腫瘍を細胞レベルで攻撃できることから，特に再発・ 転移抑制効果が期待されており，現在われわれの施設にお いて術後の Adjuvant peptide vaccine therapy の臨床研 究も行っている最中である。

現在われわれは，東京大学医科学研究所との共同臨床研 究として標準療法不応の口腔癌患者に対してペプチドワク チン療法を施行している。マイクロアレイ解析のデータに 基づいて先述の条件を満たしている, ほとんどの口腔癌で 発現している抗原分子 URLC10, TTK を同定し, 進行・ 再発口腔癌患者に対するペプチドワクチン療法を施行した。 対象は, 原発巣の再発や後発頸部リンパ節転移, 肺転移 などが生じたため, ターミナルと診断された進行・再発 口腔癌患者のうち, Performance Status (PS) 0 1で HLA-A*2402を有することが確認できた 28 例である。ぺ プチドを各 $1 \mathrm{mg}$ と不完全フロイントアジュバントを混和し てエマルジョン化したものを腋窩または鼠径部の皮下に週 1 回投与し, 4 回投与ごとに採血・画像診断により免疫細胞 の誘導および腫瘍の状態を評価した。有害事象は一部患者 でワクチン投与局所に grade I の掻痒感・発赤・硬結が認 められたのみであった。治療の結果, 300 日以上生存でき たのが 6 例，そのうちの 1 例は 800 日を超える生存が確認 されている。また, URLC10, TTKによるペプチドワクチ ン療法を受けた頭頸部がん患者 28 例の検討では, ワクチン 投与後，ほぼ全例でペプチド特異的な細胞傷害性 T 細胞の 誘導が確認できた。一方 Best Supportive Care (BSC) 群 16 例の生存期間 Overall survival (OS) の中央值が 81 日 であったのに対し，ワクチン群では 90.5 日であり，有意 に生存期間（OS）の延長が認められた。また，無増悪生
存期間 Progression free survival（PFS）においても, 中 央值がそれぞれ 59.5 日と 30 日であり，有意な延長が認め られた。

このように，口腔癌において投与したペプチドに対する 特異的免疫の活性化, 生存期間および無増悪生存期間の延 長が認められ，ペプチドワクチンの有用性は認識できた。 しかし, 腫瘤を形成してしまった口腔癌を完全に消滅させ ることはなかなか難しいのが現状である。そこで，明らか な残存腫瘍のない状態にある術後患者を対象に再発・予防 効果 (腫瘍形成抑制効果) を期待して, それは circulating tumor cells や single recurrent cell に対する活性化し た免疫細胞の傷害作用を利用する考えであるのだが，術後 Adjuvant peptide vaccine therapy を開始したところであ る。追加になるが，われわれが標的としている抗原分子は 口腔扁平上皮癌だけに限らず，口腔領域に発生した肉腫や 唾液腺癌においても発現していることを確認しており，現 在，それらの癌に対してもペプチドワクチン療法を施行し ており，効果を期待しているところである。

\section{4. 癌ワクチン療法に対する FDA ガイダンス}

2009 年 9 月に FDA から治療用癌ワクチンについての臨 床的考察 ${ }^{5)}$ が発表された。それには, 癌ワクチン療法の臨 床試験に関して免疫反応のモニタリング方法, 癌ワクチン 投与後早期および後期における腫瘍の反応性, 臨床試験の デザインなどに関する指針が示されており，それによって がんワクチン療法においてはこれまでとは異なる評価方法 が必要であることが周知となり, 癌ワクチン療法の評価に おける共通のコンセンサスが生まれつつある。FDAがん 治療用ワクチンガイダンスの要旨は, (1)従来の抗がん剂と 全く違う考え方で臨床試験をデザインする必要がある。(2) がん治療用ワクチンは臨床効果の発現に時間がかかる場合 が多い（治療効果が遅延する)。(3)残存病変のない患者や 微小ながんを持つ患者にがんワクチンを投与することで, がんワクチンによる免疫活性化のための適切な時間を確保 することができる。(4)非常にまれな状況を除き，最大耐性 量は認められなかった。(5)クチンの遅延効果のため, 生 存曲線は試験初期では効果を示さないことが多い。治療に 効果がある場合は，ワクチンの効果が現れた後，すなわち 試験後期に生存曲線の分離が生じる。といった内容であっ た6)。

今後, 臨床試験を通してがんワクチン療法の安全性を確 認し, さらにがんワクチン投与による抗腫瘍免疫の活性化 を科学的に評価し，それに伴った臨床的な抗腫瘍効果を的 確に評価していくことが重要である。 


\section{5. ペプチドワクチン療法の展望}

現在，われわれが参加しているがんペプチドワクチン全 国ネットワーク共同研究会では, 全国の大学病院や病院施 設の腫瘍内科や外科, 内科, 眼科, 免疫学講座などがそれ ぞれ, 食道癌や大腸癌, 膵藏癌, 胃癌, 肝臓癌, 肺癌, 乳 癌, 膀胱癌, 加齢性黄斑変性症などに対するペプチドワク チン療法の治験から第 I・II 相臨床試験まで行っており, 治療に登録した患者数は 1,500 人を超えている。当施設で の口腔癌においてだけでなく, 他施設の他癌種に扔いても 癌ペプチドワクチンを投与した方が投与しなかった場合と 比較して, 有意に生存期間㧍よび, 無増悪生存期間の延長 を認めている。

今後治験を通して，日本発の製剤としてペプチドワクチ ンがより多くの患者に投与できる日が来ることを心待ちに している。

\section{文献}

1) Yoshitake, Y., Nakatsura, T., et al.: Proliferation potentialrelated protein, an ideal esophageal cancer antigen for immunotherapy, identified using cDNA microarray analysis. Clinical Cancer Research $10: 6437-6448,2004$.

2) Nakatsura, T., Komori, H., et al.: Mouse homologue of a novel human oncofetal antigen, Glypican-3, evokes T cellmediated tumor rejection without autoimmune reactions in mice. Clinical Cancer Research $10: 8630-8640,2004$.

3) Harao, M., Hirata, S., et al.: HLA-A2-restricted CTL epitopes of a novel lung cancer-associated cancer testis antigen, cell division cycle associated 1, can induce tumor-reactive CTL. International Journal of Cancer $123: 2616-2625,2008$.

4) Imai, K., Hirata, S., et al.: Identification of a Novel TumorAssociated Antigen, Cadherin 3/P-Cadherin, as a Possible Target for Immunotherapy of Pancreatic, Gastric, and Colorectal Cancers. Clinical Cancer Research $14: 6487-$ 6495, 2008.

5) Guidance for Industry: Clinical Considerations for Therapeutic Cancer Vaccines, draft guidance. U.S. Department of Health and Human Services Food and Drug Administration Center for Biologics Evaluation and Research, 2009.

6）吉田浩二, 中村祐輔：消化器癌に対するがんペプチドワクチ ン療法. 日消誌 $107: 1255-1261,2010$. 


\title{
Translational research for cancer vaccine therapy using peptides originating in cancer-specific antigens is advancing
}

\author{
Yoshihiro Yoshitake, Daiki Fukuma and Masanori Shinohara \\ Department of Oral \& Maxillofacial Surgery, Graduated School of Medical Sciences, \\ Kumamoto University \\ (Chief: Prof. Masanori Shinohara)
}

\begin{abstract}
Cancer immunotherapy is expected to be the fourth treatment against cancer. OK-432 (Picibanil ${ }^{\circledR}$ ), which is dry mycelia of hemolytic streptococcus, PSK (Krestin ${ }^{\circledR}$ ), which is a protein-bound polysaccharide obtained from basidiomycetes, and Lentinan ${ }^{\circledR}$, which is polysaccharide from shiitake, are administered as anti-cancer agents. However, even when administered, patients only gain increased non-specific immunity; there is no selective attack on cancer cells. On the other hand, the peptide vaccine, which we started as a new medication for cancer vaccine therapy in this study, increases only specific anti-tumor lymphocytes which can attack only cancer cells very selectively. We report on our cancer peptide vaccine therapy against oral cancer.
\end{abstract}

Key words : cancer vaccine therapy, peptide vaccine therapy, oral cancer

Requests for reprints to: Dr. Yoshitake Y., Department of Oral \& Maxillofacial Surgery, Graduated School of Medical Sciences, Kumamoto University, 1-1-1 Honjo Kumamoto, 860-8556, Japan 